have reported values of 25 -hydroxycholecalciferol of over $749 \mathrm{nmol} / 1$ $(300 \mathrm{ng} / \mathrm{ml})$ in vitamin $\mathrm{D}$ intoxication, and the value in the present case was even greater. It is not clear how much calciferol was being ingested, but the lack of response of the hypercalcaemia to treatment with prednisolone could have been due to consumption of a very high dose.

1 Asher, R, Lancet, 1951, 1, 339

2 Addison, G M, et al, fournal of Endocrinology, 1971, 49, 521

3 Preece, M A, et al, Clinica Chemica Acta, 1974, 54, 235.

4 O'Riordan, J L H, et al, Clinical Endocrinology, 1972, 1, 149.

5 Preece, M A, et al, Quarterly fournal of Medicine, 1975, 44, 575.

Department of Metabolism and Endocrinology, The London Hospital Medical College, London E1

P E BELCHETZ, MSC, MRCP, lecturer (present address: MRC Clinical Research Centre, Northwick Park Hospital, Harrow, Middlesex)

R D COHEN, MD, FRCP, professor of metabolic medicine

The Medical Unit, The Middlesex Hospital, London W1

J L H O'RIORDAN, DM, FRCP, deputy director

S TOMLINSON, MB, MRCP, MRC clinical research fellow

\section{Aflatoxin inhalation and alveolar cell carcinoma}

Aflatoxin, a toxic metabolite of the mould Aspergillus flavus, is one of the most potent carcinogens known. ${ }^{1}$ Epidemiological studies in tropical areas have shown that the high incidence of primary liver cancer in their populations may be related to the ingestion of contaminated food. ${ }^{2} 3$ This paper reports a case of pulmonary adenomatosis due possibly to inhalation of aflatoxin.

\section{Case report}

A chemical engineer aged 68 worked for three months on a method of sterilising Brazilian peanutmeal which was contaminated by the mould Aspergillus flavus. Three months after finishing this work he became ill with high fever and began to expectorate thick, white sputum. $X$-ray examination showed cavitation in the left lower lobe of the lung. At first the process was considered to be due to tuberculosis, and later to mycotic disease. After two months further lesions developed in both lungs. The condition of the patient became worse and he died 11 months after the onset of his illness. Necropsy showed enlarged, heavy lungs diffusely infiltrated with firm yellow-white or reddish lesions.

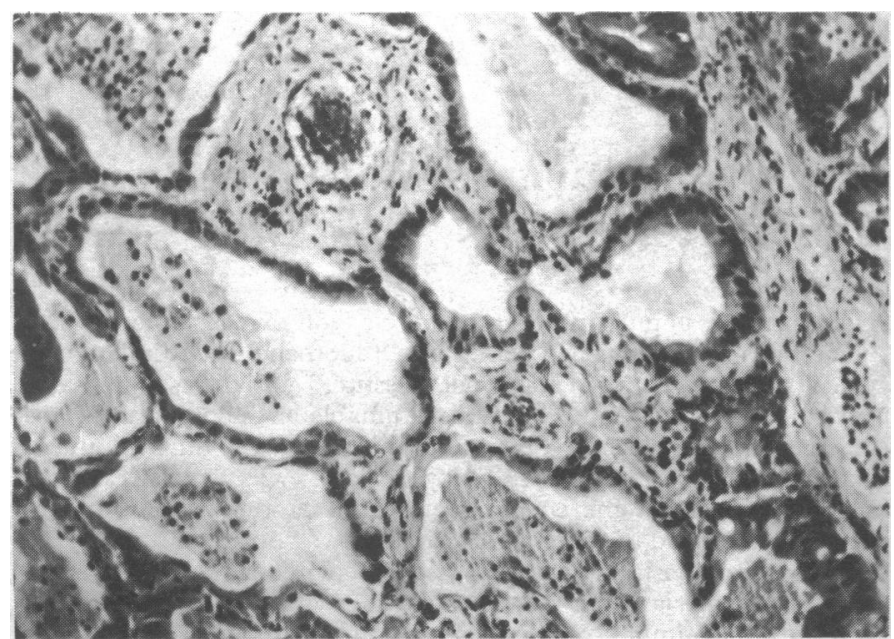

Section of lung. Interalveolar septa well preserved. Alveoli lined with high cylindrical or cubical epithelium. (Haematoxylin and eosin. $\times 95$.)
Histological examination (see fig) showed bands of fibrous tissue in the parenchyma. The alveoli were lined with high cylindrical or cubital epithelium with giant multinucleated cells, some containing mucous vacuoles in their plasma. The interalveolar septa were well preserved. Mitotic figures were rare. The picture was that of pulmonary adenomatosis. No metastases or tumours in other organs were found. Bacteriological examination was negative. A sample of lung tissue was taken for chemical investigation. Thin-layer chromatography of the extract showed a blue fluorescent spot in $365 \mathrm{~nm}$ UV light similar to that of a commercial sample of aflatoxin $B_{1}$ (Calbiochem, California), the same colour change as standard $B_{1}$ when treated with $50 \% \mathrm{H}_{2} \mathrm{SO}_{4}$, and an $\mathrm{RF}$ value identical to that of the commercial aflatoxin sample $B_{1}$. A colleague of this patient who had been doing the same work had died three years before of pulmonary adenomatosis, but no chemical investigations were done in his case.

\section{Discussion}

The pathogenesis and aetiology of primary pulmonary adenomatosis is not clear. It often develops at the site of fibrous scars of inflammatory origin or in a lung chronically damaged from other causes. Eversole and Rienhoff ${ }^{4}$ suggested that it is due to congenital malformations, while Spencer ${ }^{5}$ thought it was caused by the inhalation of irritant substances together with other factors that lead to chronic damage to the lung. It seems that men who inhale toxic mould during their work might well be at risk.

1 Butler, W H, Greenblatt, M, and Lijinsky, M, Cancer Research, 1969, 29, 2206.

2 Hutt, A M, Wogan, G N, and Davidson, C S, Gastroenterology, 1972, 62, 1094.

3 Peers, F G, Linsell, C A, British fournal of Cancer, 1973, 27, 473.

4 Eversole, S L, and Rienhoff, W F, fournal of Thoracic and Cardiovascular Surgery, 1959, 37, 750.

5 Spencer, H, Pathology of the Lung, p 660. London, Pergamon Press, 1963.

Department of Parhology, Charles University, Hradec Králové, Czechoslovakia

IVANA DVOŘÁCKOVÁ, MD

\section{Pulmonary asbestosis and autoimmunity}

Experimental animals exposed to silica particles form rheumatoid factor. 1 Rheumatoid factor and antinuclear antibodies have also been found in persons exposed to asbestos and in patients with pulmonary asbestosis. ${ }^{2}$ Autoimmunity might therefore be implicated in causing the pulmonary lesions of asbestosis. The inhaled asbestos fibres would cause cellular damage, tissue antigens would be released, and autoimmune antibodies formed. Furthermore, HLA-27 antigen, known to be associated with diseases of possible autoimmune aetio$\operatorname{logy},{ }^{3}$ is often present in patients with asbestosis.

Antophyllite, a relatively rare kind of asbestos, is mined in Finland. The incidence of pulmonary tuberculosis and of pulmonary carcinoma is high, ${ }^{4}$ and they occur not only in the factory workers but also in people living close to the mines. ${ }^{5}$ If autoimmune mechanisms played a part in the pathogenesis of their disease we would expect to find rheumatoid factor or antinuclear antibodies in their sera. We therefore examined the sera of all the quarry and fibre mill workers for the presence of rheumatoid factor and antinuclear antibodies.

\section{Methods and results}

In all, 66 sera were studied from men who had been working with asbesto for 2 to 38 years, the average being $15 \cdot 2$ years. None had severe asbestosis. We used the Waaler-Rose test for the rheumatoid factor and the fluorescent antibody test for antinuclear antibodies, as used routinely in our laboratory. Both positive and negative control sera were included in all test series.

A Waaler-Rose titre $>1 / 32$ was found in seven $(10.7 \%)$ and a titre of $>1 / 64$ in three $(4.5 \%)$ of the 66 sera. Antinuclear antibodies were seen in only one serum. The titre with FITC conjugated antihuman immunoglobulin was $1 / 80$ and with antihuman $\operatorname{IgG} 1 / 10$. These findings are the same as those in the normal healthy population. 


\section{Comment}

Antinuclear antibodies and the rheumatoid factor in cases of asbestosis probably result from the pulmonary lesions and are not evidence of an autoimmune mechanism in the pathogenesis of the disease. Another probable explanation of the negative finding in our cases is that antophyllite, owing to its different physicochemical structure, causes less destruction of lung tissue than other asbestos materials.

1 Pernis, B, et al, Folia Allergologica, 1963, 10, 396.

2 Turner-Warwick, M, and Parker, W R, British Medical fournal, 1970, 3, 492.

${ }^{3}$ Merchant, J A, et al, British Medical fournal, 1975, 1, 189.

4 Nurminen, M, Work-Environment-Health, 1972, 9, 112

5 Meurman, L, Acta Pathologica et Microbiologica Scandinavica, 1966, suppl 181 .

\section{University of Turku, 20520 Turku 52, Finland}

AULI TOIVANEN, MD, senior lecturer, department of medicine

MARJA SALMIVALLI, MD, physician for occupational health in building material industries

GÁBOR MOLNAR, MD, assistant physician, department of medical microbiology

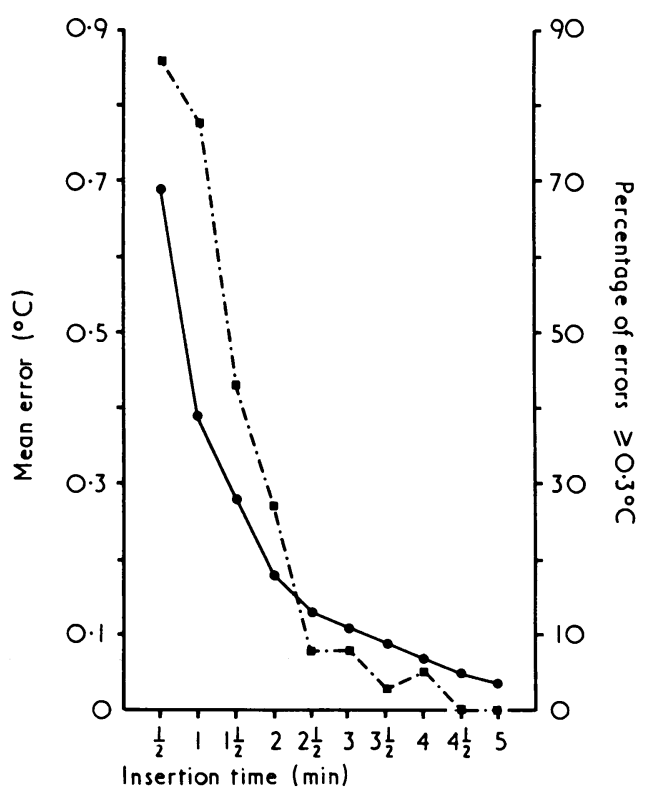

Mean errors (continuous line) and percentages of errors $\geqslant 0.3^{\circ} \mathrm{C}$ (broken line) in relation to insertion time.

\section{Comment}

The criteria by which a satisfactory insertion time is defined are arbitrary. We feel, however, that two minutes, after which $27 \%$ of temperatures recorded in our study had "errors" of $0.3^{\circ} \mathrm{C}$ or more, is not sufficient. On the basis of our results we would join De Nosaquo and his colleagues in recommending a time of at least three minutes. It is important that temperatures should be measured accurately, so that low-grade fevers are not missed and that the pattern of a fever may be followed, both as an aid to diagnosis and as a guide to the efficacy of treatment.

We would like to thank Dr A J Honour and Dr B E Juel-Jensen for their advice and encouragement.

${ }^{1}$ De Nosaquo, N, et al, fournal of Laboratory and Clinical Medicine, 1944, 29, 179.

${ }^{2}$ Nursing Times, 1971, 67, 1139.

that most authors advise that thermometers need be kept in the mouth for only two minutes. In practice, where there is a high pressure of work, this time is often reduced to a minute or even less. We have re-examined the effect on readings of leaving thermometers in place for different periods.

\section{Methods and results}

Three clinical thermometers, each with a differently shaped bulb, were used. Two were calibrated in ${ }^{\circ} \mathrm{C}$ and read to the nearest $0 \cdot 1^{\circ} \mathrm{C}$. The third, which was calibrated in ${ }^{\circ} \mathrm{F}$, was read to the nearest $0 \cdot 2^{\circ} \mathrm{F}$. The accuracy and rate of equilibration of the thermometers were tested in a thermostatically controlled water bath against a standard thermometer reading to $0.01^{\circ} \mathrm{C}$. It was shown that each thermometer was accurate to within $0 \cdot 1^{\circ} \mathrm{C}\left(0 \cdot 2^{\circ} \mathrm{F}\right)$, and attained its maximum within 10 seconds. Thirty-two people took part in the study. Nineteen were healthy volunteers (mostly medical students) and 13 were inpatients. We performed 37 experiments. In each experiment one person and one thermometer were used, and 10 readings of the thermometer were recorded. These readings were taken after leaving the thermometer in the mouth for each of the 10 insertion times: $\frac{1}{2}, 1,1 \frac{1}{2}, 2$, $2 \frac{1}{2}, 3,3 \frac{1}{2}, 4,4 \frac{1}{2}, 5$ minutes. These 10 measurements were made in random order. For five minutes before starting, and then throughout the duration of an experiment, the subject was kept in an environment with a temperature constant to $1^{\circ} \mathrm{C}$. He was required not to drink or smoke during this period and conversation was kept to a minimum. Before taking each temperature the thermometer was cooled for at least 30 seconds in a beaker of water at room temperature, and the mercury shaken down to below the scale. Subjects were asked to ensure that the thermometer stayed well under the tongue while temperatures were being taken.

In each experiment a note was made of the highest temperature recorded. The difference between this maximum and each reading in the experiment was deemed the "error" of that reading. The figure shows the mean error when averaged over all experiments and expressed in ${ }^{\circ} \mathrm{C}$, plotted against insertion time. Also shown is the percentage of individual errors of $0.3^{\circ} \mathrm{C}$ or more.
University Department of Social and Community Medicine, Oxford
OX13QN
D N M COGGON, BA, clinical student
M P VESSEY, MA, MD, professor

\section{Explosion during halothane anaesthesia}

Halothane is popularly regarded as a non-explosive anaesthetic. Quotations from published work state "[fluothane] is not inflammable when mixed with oxygen at normal pressure." "Mixtures of fluothane, oxygen, and nitrous oxide are non-flammable in the proportions used in anaesthetic practice." "Fluothane ignites at $1 \% \mathrm{v} / \mathrm{v}$ in $99 \%$ nitrous oxide and $4 \% \mathrm{v} / \mathrm{v}$ in $24 \%$ oxygen and $72 \%$ nitrous oxide." ICI Ltd state that the energy required to produce this would not normally be found in anaesthetic practice.

I therefore wish to report a case of halothane explosion during dental anaesthesia. After induction of the tenth case of the morning, say, after 45 minutes' continuous anaesthesia, a loud bang occurred; simultaneously a spark and a blue flame was seen inside the halothane vaporiser. The flame did not appear at the nose piece, which was 